\title{
Wage Inequality in Post-Reform Mexico
}

\author{
Jim Airola ${ }^{1}$ \\ Naval Postgraduate School \\ Chinhui Juhn \\ University of Houston
}

January 2005

\begin{abstract}
Using the Mexican Household Income and Expenditure Survey (ENIGH) covering 1984-2000 we analyze wages and employment in Mexico after trade liberalization and domestic reforms. We find that wage inequality and returns to postsecondary schooling increased rapidly during 1984-1994 but stabilized since that period. The end of inequality growth was due to a severe macroeconomic crisis which adversely impacted the better educated, an increase in education levels at the end of the 1990s, and a slowdown in skill demand in the latter half of the 1990s. Between-industry shifts, consistent with trade-based explanations, account for a part of the increase in skill demand during 1984-1994, but these types of movements actually reduced the demand for skill in the latter part of the 1990s. The equalizing impact of trade was offset by within-industry demand shifts which continued to favor more educated workers. The Mexican experience in the 1990s suggests that market-oriented reforms have a sharp initial impact on inequality which dissipates over time. However, the opening of the economy to trade, foreign capital, and global markets also leads to a more long-run increase in the demand for skill.
\end{abstract}

\footnotetext{
${ }^{1}$ Jim Airola: DRMI, Naval Postgraduate School, Monterey, CA 93943, (Tel) 831-656-2457, (Email) jsairola@nps.edu; Chinhui Juhn: Department of Economics, University of Houston, Houston, TX 772045882, (Tel) 713-743-3823, (Email ) cjuhn@uh.edu .
} 


\section{Introduction}

During the 1980s, wage inequality dramatically expanded in many OECD countries and particularly in the United States. While researchers have reached a near consensus that these changes are related to an increase in demand for more educated workers, a sharp debate has ensued regarding the cause of this increase in skill demand. One set of explanations focus on skill-biased technological change associated with the widespread use of computers and information technology (Bound and Johnson (1992), Krueger (1993), Berman, Bound, and Griliches (1994), Autor, Katz, and Kreuger (1998)). Another set of explanations emphasizes the effects of globalization and trade with countries abundant in unskilled labor (Wood (1994), Borjas and Ramey (1995), Leamer (1996)).

One approach to testing for the Stolper-Samuelson effects of trade has been to examine wage changes in developing countries. If import competition from low wage countries put downward pressures on the wages of unskilled workers in the developed countries, then we should observe opposite movements in wages in developing countries. Contrary to these predictions, however, a number of studies have documented that wage inequality actually increased in Mexico and most Latin American countries as they opened to trade (Feliciano (2001), Robbins (1994), Wood (1997)).

This study uses 7 rounds of the Mexican Household Income and Expenditure Survey (ENIGH), available over the period 1984-2000, to analyze changes in wage inequality in Mexico after the adoption of market-oriented reforms and opening to international trade. The ENIGH is a nationally representative survey covering rural as well as urban households and therefore has a major advantage over the often-used Urban 
Employment Survey. We perform an in-depth analysis of the wage structure, examining education premiums as well as inequality changes within demographic and skill groups. We investigate whether movements in relative wages and quantities are consistent with shifts in skill demand and calculate shifts in employment and wage bill shares within and between industries. These methods have been employed extensively to study the relative importance of trade and skill-biased technological change in the U.S. (Katz and Murphy (1992), Berman, Bound, and Griliches (1994), Autor, Katz, and Krueger (1998)). We also evaluate the role of outsourcing by comparing the wage-bill shares of educated workers across regions with differential growth in maquiladora (off-shore assembly plant) employment.

\section{Related Literature}

Different explanations have been offered to explain the increase in wage inequality in Mexico. A number of papers argue that previous to trade reform, the import substitution policies of countries such as Mexico disproportionately protected low skilled labor. Using plant-level data from Mexican manufacturing, Revenga (1997) finds that trade liberalization reduced rents paid to workers in protected sectors and that the initially protected sectors were low skilled and more labor intensive. Using the same data, Hanson and Harrison (1999) also find that reductions in tariff protection disproportionately affected lower-skilled industries although they find no significant relationship between product price changes and skill ratios. Robertson (2001) concludes that tariff reductions increased the relative price of skill-intensive goods during the 1987- 
1993 period. These papers conclude that movements in skill ratios were entirely consistent with Stolper-Samuelson effects although product price changes following trade liberalization were counter to expectations due to the initial protection of low skillintensive sectors.

Another trade-based explanation for the rising inequality in Mexico is outsourcing by foreign firms. Feenstra and Hanson (1996) develop a model of outsourcing in which less skill-intensive stages of production move from the "North" to the "South" and increase skill premiums in both regions. Using offshore assembly plants, called maquiladoras, as the measure of this type of foreign direct investment, Feenstra and Hanson (1997) show that FDI is positively correlated with increases in wage bill share of non-production workers across states in Mexico. As with other studies that use manufacturing data, it is difficult to assess to what extent manufacturing affects wages economy-wide and to what extent the distinction between non-production and production workers proxies for skill. Their analysis also ends in 1988 just before the sharp increase in wage inequality we document here.

In addition to trade liberalization, Mexico instituted a series of other marketoriented reforms that substantially liberalized the economy starting in the mid-1980s. These market-oriented reforms included privatization, reform of domestic financial markets and capital market liberalization. Trade liberalization began with the GATT Agreement in 1986 and culminated with the passage of NAFTA in 1992. The timing of these other reforms coincided with trade liberalization. Behrman, Birdsall, and Szekely (2000) use household data from18 different Latin American countries and find that domestic financial market reforms and capital account liberalization, in particular, lead to 
increases in the skill premium in the initial stages. Trade reforms may have an equalizing effect, but only with some time lag. Cragg and Epelbaum (1996) point to these other reforms as the major explanation for rising inequality in Mexico in the early 1990s. They find that skill premiums increased in all industries and thus reject explanations based on tariff reductions and rent dissipation. Using the same household survey of urban areas used by Cragg and Epelbaum, Meza-Gonzalez (1997) also finds that the increase in skill demand for college-educated workers was entirely due to "within" rather than "between" industry shifts.

What explanations are consistent with the "within-industry" demand shifts documented in these papers? One explanation is skill-biased technological change (Berman, Bound, and Machin (1998), Berman and Machin (2000)). The adoption of skill biased technology may in fact be enhanced by trade opening if domestic firms invest in capital and foreign technology to compete (Attanasio, Goldberg, and Pavcnik (2003)). Recent papers by Esquivel and Rodgriguez-Lopez (2003) and Melendez (2001) use the “mandated wage” equations suggested by Leamer (1997) to disentangle the impact of technology and trade. They find that total factor productivity changes, not product price changes, were associated with the wage inequality increase. Melendez (2001) also shows that there is a positive correlation between total factor productivity growth and share of foreign capital. The link between trade, foreign investment and skill-biased technology has been difficult to document empirically in the context of other countries such as Chile (Pavcnik (2002)). Most empirical studies have also been restricted to the manufacturing sector which leaves open the question, what has lead to the rapid skill-upgrading in the non-manufacturing sector? 
Cragg and Epelbaum (1996) and Szekely (1998) argue that economic liberalization in Mexico created an environment of change that favored the educated and those with entrepreneurial ability. This notion is related to papers in the growth literature, which suggest that returns to ability rise during period of innovation and change (Nelson and Phelps (1966), Welch (1970), Schultz (1975), Bartel and Lichtenberg (1987), Galor and Tsiddon (1997)).

Our paper complements and extends the previous research. A major contribution of our work is that we examine a longer time span using a nationally representative survey. The extension of the analysis to the latter half of the 1990s is crucial for understanding the long-run impact of trade liberalization and market-oriented reforms. We find that wage inequality and skill premiums stabilized after 1994. The slowing was due to a combination of factors. The severe macroeconomic conditions brought on by the peso devaluation in 1995 adversely impacted the better educated workers. Education levels also increased sharply from 1998-2000. Finally, skill demand slowed relative to the earlier period. On the one hand, the slowdown suggests that part of the sharp increase in inequality during the early 1990s was a short-run reform effect as suggested by Behrman, Birdsall, and Szekeley (2000). On the other hand, the continued increase in skill demand suggests that the opening of the economy to trade, foreign investment and global markets has a long- run disequalizing impact on the wage structure.

Our analysis of the latter half of the 1990s suggests that between- industry shifts actually reduced the relative demand for workers with post-secondary education, as would be predicted by the standard Heckscher-Ohlin model. However, this equalizing impact of trade was offset by continued skill-upgrading within industries which widened 
the wage structure. While consistent with skill-biased technical change, the household data we employ here is not ideally suited for answering precisely what accounts for this within-industry skill upgrading.

Our paper also examines the impact of outsourcing in the 1990s. In contrast to the results documented by Feenstra and Hanson (1997) for the 1980s, we find that regions that experienced the largest increases in maquiladora employment also had the slowest growth in skill demand in the 1990s.

\section{Macroeconomic Background}

In this section, we briefly review the macroeconomic developments in Mexico during the period of our analysis. Following the oil price collapse in 1982, the Mexican economy entered a severe recession. Between 1982 and 1986, real per capita GDP fell approximately 22 percent (see figure III.1). This economic crisis spurred the succeeding governments to embrace policies of privatization and market-oriented reforms. In 1982, the public sector officially registered 1,155 public enterprises. By the end of 1993, 1,019 had been sold, merged, or closed. The sale of TELMEX in 1990 was the single largest privatization. Other privatizations took place in airlines, sugar mills, mining, tobacco, steel, dairy, fertilizers, trucking, insurance, radio, television, and movie theaters. By the end of 1993, more than 17 laws had been reformed and more than forty regulatory frameworks altered. Furthermore, a federal law was passed in 1992 making it more difficult for legislators to enact any new regulations affecting economic activity. New 
antitrust legislation was introduced in 1992 to promote competitive markets and in December 1993, a law was passed promoting foreign direct investment (Roett, 1998).

Although Mexico officially signed the GATT agreements in 1986, it is important to note that the GATT included an escape clause that provides for the suspension of free trade via tariffs when increased imports "cause or threaten serious injury to domestic producers.” (Article XIX, General Agreement on Tariffs and Trade, 1947). It was in mid-1987 that the government began in earnest to open Mexico’s borders. It eliminated most trade permits and decreased tariffs by about 14 percent on average. Following this, the government entered trade negotiations with the U.S. and Canada leading to NAFTA, which went into effect in 1994.

In figure III.2 we graph the reform indices compiled by Morley, Machado, and Pettinato (1999) and used by Behrman, Birdsall, and Szekely (2000). These reform indices are designed to reflect policy “effort” towards liberalization and openness rather than outcome and consist of the following: 1) trade reform largely reflecting tariff rates 2) domestic financial market reform which controls for borrowing and lending rates at banks and reserve ratios 3) international financial liberalization which reflects controls on foreign investment, repatriation of profits, and controls on capital flows 4) tax reform reflecting tax rates and 5) privatization index based on the ratio of non-farm private sector output to value of output from state-owned enterprises. The indices are normalized between 0 and 1 where 0 is the minimum value and 1 is the maximum value observed among all Latin America countries during the period 1970-1995. We see from figure III.2 that since the early 1980s, Mexico has moved towards a market-oriented economy 
based on all reform indices. The efforts were particularly pronounced in privatization, domestic financial market reforms and opening of capital markets to foreign investors.

As illustrated in figure III.1, real per capita GDP slowly recovered through the late 1980s and early 1990s until the peso devaluation in 1994-95. Following the devaluation, real GDP fell 6 percent and only recently recovered to the pre-crisis level. Both the devaluation of the peso and the passage of NAFTA may have contributed to the boost in non-oil exports, which rose from being approximately 10 percent of GDP to being nearly 30 percent by 2000 . While it may be too early to tell, the sharp increase in exports post-NAFTA suggests that we may have a better chance of identifying the effects of trade on wages after this period. The figure also suggests that changes over the 19941996 period may be non-representative of the underlying trends due to the severe macroeconomic crisis. In the following analysis, we focus on the 1996-2000 period to isolate the long-run effects of trade liberalization and other domestic reforms.

\section{Data}

We use data from 7 rounds of the Household Income and Expenditure Surveys (ENIGH) spanning the period 1984-2000. The income and demographics supplements of ENIGH, which we utilize in this paper, have a similar structure to the Current Population Surveys in the United States and contain individual and household level information on demographic characteristics, employment, and earnings. The major summary statistics are presented in appendix table 1. 
The ENIGH have several advantages over the often-used Urban Employment Survey. Unlike the Urban Employment Survey, which covers the 16 largest urban areas accounting for about one third of the population, the ENIGH is a nationally representative survey. ${ }^{2}$ The other advantage is that it begins in 1984 well before the major reform efforts were under way. Table IV.1 illustrates the difference between the ENIGH and the Urban Employment Surveys in 1992 when both surveys were conducted. Among individuals aged 16-65, approximately 13.0 percent reported they had no education and 9.0 percent reported they had post-secondary education in ENIGH. In comparison, the sample in the Urban Employment Survey was much better educated with only 4.6 percent reporting they had no education and 14.0 percent reporting they had post-secondary education. Mexico is considerably less urbanized than other middle-income countries in Latin America such as Uruguay and Argentina. Focusing on the urban population can lead to partial and sometimes misleading picture of the whole economy. Cragg and Epelbaum (1996) utilize the Urban Employment Survey and report that average real wages increased 30 percent between 1987 and 1993. As we later show, average hourly wages, including the rural areas, essentially remained unchanged from 1984 to 1994. While being representative at the national level is its great advantage, one disadvantage of the ENIGH is its much smaller samples relative to the Urban Employment Survey.

For calculating wages we construct a wage sample consisting of men and women who are 15-64 years old, who worked at least 30 hours during the survey week and reported no self-employment income. Wages are calculated as reported wage and salary

\footnotetext{
${ }^{2}$ Until 1992, the ENUE included 16 cities, the 12 largest and 4 border cities. These 16 cities comprised $60 \%$ of the urban population which in turn, comprised about 60 percent of total population (Cragg and Epelbaum, 1996). Successive surveys have increased representativeness.
} 
earnings last month divided by the product of weekly hours and 4.33. Earnings were deflated by the national consumer price index published by the Bank of Mexico with 1994 as the base year.

For reporting quantities of labor by education and by industry, we construct a sample of 15-64 year olds who report positive hours during the survey week, including the self-employed. We report hours-weighted employment shares and shares in efficiency units of labor. To calculate efficiency units, we first calculate average wages (fixed across all years) by 2 gender, 10 age and 8 education categories. We weight hours by these average wages to calculate efficiency units of labor. All our calculations are weighted by the household weights to make the sample nationally representative.

\section{Wage Inequality and Skill Premiums}

\section{A. Overall Inequality}

In this section we examine changes in wage inequality and skill premiums in Mexico from 1984 to 2000. Table V.1 presents changes in average log hourly wages by quintiles of the wage distribution between successive surveys. ${ }^{3}$ Table V.1 shows that average hourly wages essentially remained flat until 1994 and fell 36 percent from 1994 to 1996, the period of the peso crisis. Real wages have recovered somewhat, rising by 22 percent from 1996 to 2000.

\footnotetext{
${ }^{3}$ We divided observations into groups disaggregated by year, gender and five quintile categories based on relative position in the wage distribution and calculated average log hourly wages within groups.
} 
In terms of relative wages, the top quintile mostly gained during the first decade of our data, 1984-1994, while real wages mostly declined for the lower wage groups leading to an increase in overall wage inequality. Table V.2 reports selected inequality measures. The 90-10 log wage differential among men increased from 1.86 in 1984 to 2.16 in 1994, an increase of about 30 percent in the relative wage. The entire increase was accounted for by an increase in inequality between the middle and the top of the distribution. The 90-50 differential increased almost 40 percent while the 50-10 actually fell 8 percent. Among women, the 90-10 log wage differential expanded by similar amounts, again entirely fueled by an increase in the top half of the distribution.

Interestingly, the macroeconomic crisis over the 1994-1996 period resulted in larger real wage declines for the higher wage groups leading to a decline in wage inequality. The negative impact of the crisis on better educated and more skilled workers has also been noted by other papers (Attanasio and Szekeley (2001), McKenzie (2001)). While per capita GDP and real wages have recovered, overall inequality, as measured by the 90-10 differential, continued to decline over the 1996-2000 period. In the following section we investigate whether supply or demand changes account for stabilizing inequality in the later period.

\section{B. Education and Occupation Premiums}

Figure V.1 and figure V.2 illustrate returns to education for men and women from 1984-2000. We distinguish three broad education categories, those with a primary education or less (0-5 years), those with middle to high school education (6-12 years), and those with post-secondary education (more than 12 years). Thus we group those who 
report they had some post-secondary schooling with college graduates as our most educated group. Figure V.1 shows differences in average log wages between those with post-secondary education and those in the middle education category. ${ }^{4}$ Returns to postsecondary education remained essentially flat between 1984 and 1989 but rose dramatically in the early 1990s, rising by approximately 30 percent. Similar to trends in overall inequality, however, returns to post-secondary education have stabilized since the dramatic increase in first half of the 1990s. Figure V.2 presents the differential between the middle and bottom education categories. Returns to secondary education have fallen slightly for both men and women since 1984 .

An alternative measure of the skill premium is the wage differential across occupations. Figure V.3 and figure V.4 present differentials between three broad occupation categories. The high skilled group includes professionals and executives. The medium skilled group includes blue-collar occupations such as operatives and craftsmen as well white-collar occupations such as office, sales and clerical workers. The low skilled group includes farm laborers and service workers. Figure V.3 confirms that the wage premium paid to the high skilled workers increased sharply during 1989-1994 but remained flat or even declined slightly since that period. Figure V.4 shows that the relative wage of medium skilled to low skilled occupations has remained remarkably stable for men and has actually declined for women since 1984.

\section{Within-Group Inequality}

\footnotetext{
${ }^{4}$ We corrected for a quadratic age-earnings profile estimated over all years. This method is similar in spirit to aggregating across age groups using a fixed age distribution.
} 
In the U.S., wage dispersion increased both between and within observable groups. Although controversial, one interpretation of the rise in within-group inequality has been an increase in returns to unobserved skills or ability (Juhn, Murphy, and Pierce (1993)). Szekely (1998) suggests that privatization and other domestic reforms created an environment of change rewarding ability and entrepreneurship. We investigate this possibility by examining inequality changes within education category in figure V.5 and figure V.6.

Figure V.5 examines changes over the initial period of rapid inequality rise, 19841994. The top panel of figure V.5 presents wage changes by percentile for men in different education categories. The bottom panel presents the numbers for women. The figure shows that within-group inequality rose sharply among men with post-secondary education, with the highest wage groups enjoying the largest wage increases over this decade. Among those with a secondary education, only those in highest wage categories experienced wage growth. Among the least educated, there was essentially little inequality growth.

Figure V.6 presents the within-group inequality changes for the latter period, 1996-2000. The figure indicates that among men with post-secondary education, withingroup inequality continued to increase during this latter period, with the high wage groups gaining significantly more than the low wage groups. This is not true for women as illustrated in the bottom panel. Among highly educated women, within-group inequality actually fell in the most recent period. Under the assumption that the supply of unobserved skills and ability are stable across periods, figure V.6 suggests that demand 
for unobserved skills continued to increase for highly educated men but not for highly educated women.

\section{Inclusion of Self-Employment Earnings}

We also investigated whether our inequality story is substantially altered if we include self-employed workers. In a recent paper, Attanasio, Goldberg, and Pavcnik (2003) find that foreign competition following trade liberalization increased the size of the informal sector in Colombia. One concern is that lower skilled workers may leave wage and salary employment and become self-employed during hard economic times. This "dropping" out of workers with the lowest opportunities may be one reason for the actual decline in wage dispersion between the $50^{\text {th }}$ and the $10^{\text {th }}$ wage percentiles. We report our results in appendix table 2 and highlight the major findings here. Among male workers, the 90-10 differential, including the self-employed, increased approximately 22 percent from 1984 to 1994, in contrast to the 30 percent increase observed among wage and salary workers. Most importantly, wage dispersion in the bottom half of the distribution declines even more when we include the self-employed. From 1984 to 1994, the 50-10 differential among men fell approximately 12 percent, in contrast to the 8 percent decline observed among wage and salary workers. We conclude that the rise in inequality is muted when we include self-employment earnings, but the substance of our message is not altered. ${ }^{5}$

\footnotetext{
${ }^{5}$ We also investigated the possibility that the sharp increase in wage inequality concentrated over a relatively short time period, 1989-1994, was mainly due to changes in compensation policy such as a greater reliance on bonuses and merit pay. To address this question, we excluded earnings not specified as "wages,salaries, and overtime" which may include bonuses or merit pay. Our results are virtually identical when we exclude this component of earnings, which suggests that bonus pay is not an important part of the story. It is also possible that our self-reported earnings data are not ideally suited for answering this question.
} 


\section{Education and Supply of Skill}

The previous section documented that the relative wage of workers with postsecondary education increased sharply in Mexico during 1984-1994. In the U.S., the observation that relative wages and employment share of college graduates both increased lead researchers to conclude that demand for college graduate workers increased (Katz and Murphy (1992), Murphy and Welch (1992) Bound and Johnson (1992), Autor and Katz (1999)). In this section we begin by documenting relative supply changes and examine whether these changes, together with relative wage changes, are consistent with an increase in demand for skill. The previous section also noted returns to post-secondary education stabilized in the latter period, 1996-2000. We examine whether stabilization of returns was due to slowdown in skill demand or increase in the pace of educational upgrading in the economy.

Table VI.1 presents shares of workers by education category. The top panel reports the education distribution where each worker is weighted by hours. Following Katz and Murphy (1992), we also report hours-weighted efficiency units of labor as shares of total labor in the second panel. Finally we present wage bill shares of workers by education category in the bottom panel. Wage bill shares incorporate changes in both relative wages and relative quantities. Autor, Katz, and Krueger (1998) show that under the assumption that the production function is Cobb-Douglas and the elasticity of substitution between skilled and unskilled workers equals 1, changes in wage bill share can be interpreted as relative demand shifts. ${ }^{6}$

\footnotetext{
${ }^{6}$ To calculate efficiency units of labor, we begin with a sample of all workers aged 15-64. We calculate average wages by 2 gender, 10 age and 8 education categories. We weight hours by these average
} 
Examining hours illustrated in the top panel, we see that the share of the least educated group fell dramatically from 70.6 percent in 1984 to 44.0 percent in 2000. Meanwhile, labor shares of all other groups increased. From 1984 to 1994, the labor shares of workers with medium levels of education (secondary plus high school) increased from 22.6 percent to 36.0 percent, an increase of approximately 47 percent. The share of workers with post-secondary education increased by a comparable amount in percentage terms, rising by approximately 48 percent. We conclude from the table that between 1984 and 1994, the share of workers with post-secondary education stayed about constant relative to those with secondary schooling, but increased relative to the less educated population as a whole. The simultaneous increase in relative wage and relative supply of workers with post-secondary education suggests that demand for these highly educated workers increased over the period. The wage bill shares in panel C also point to an increase in demand. The wage bill share of workers with post-secondary schooling increased from 17.1 percent in 1984 to 33.1 percent in 1994.

What happened to the supply of skill in the later period, 1996-2000? Table VI.1 shows a sharp increase in the share of post-secondary workers from 1998 to 2000. Over these years, labor share in hours increased from 11.6 percent to 13.8 percent and wage bill share increased from 32.1 percent to 37.1 percent. While relative wages of postsecondary workers stagnated, relative quantities sharply increased, suggesting that the overall demand for skill continued to increase.

wages to calculate efficiency units and wage bills. Since we use wages of wage and salary workers only, our method imputes wages for the self-employed. For efficiency units, we fix group wages at the average value for the entire period while for wage bills we allow the wages to vary over time. 
The bottom rows of the panel make explicit comparisons across the two periods by examining annualized changes in the share of post-secondary workers. Quantity increases were similar across the two decades with the labor share of post-secondary workers in efficiency units rising approximately 1.5 percent per year. Changes in wage bill shares illustrated in the very bottom row suggest that skill demand continued to increase in the latter half of the 1990s but at a slower rate. Wage bill shares of postsecondary workers increased at an annual pace of approximately 2.9 percent during the first decade of the reform, and slowed to the rate of 1.6 percent per year.

\section{Between and Within-Industry Demand Shifts}

Many papers assessing the relative importance of trade and skill-biased technological change in the U.S. have examined changes in the non-production to production worker ratio within detailed manufacturing industries. If product demand changes or international trade were the major causal factors, then we might have observed large movements of labor between industries, particularly towards those that employ more skilled labor. In fact, researchers have found that the wage bill share of skilled workers increased within narrowly defined industries and this type of "withinindustry" skill upgrading made up the bulk of the total change in skill demand. (Berman, Bound, and Griliches (1994), Lawrence and Slaughter (1993), Berman, Bound, and Machin (1998), Autor, Krueger, and Katz (1998), Berman and Machin (2000).

Within-industry demand shifts have also been shown to play a predominant role in Mexico during the period of sharp inequality rise in the early 1990s (Cragg and 
Epelbaum (1996), Meza-Gonzalez (1997), Melendez (2001)). In the following section, we present within and between-industry changes in employment and wage bill share of workers with post-secondary education. We particularly focus on the later period after the macroeconomic crisis, 1996-2000, to see to what extent the patterns of skill demand observed over the first decade continued into the later period.

We first begin by describing changes in the industrial composition of employment. Table VII.1 begins by reporting labor shares across broad industry classes. Again we report labor shares in hours-weighted efficiency units. The most significant change reported in the table is the declining share of agriculture throughout the period. The share of total labor in agriculture fell from 23.2 percent in 1984 to 9.6 percent in 2000. From 1984 to 1994, the share fell nearly 10 percentage points. Somewhat surprisingly, the manufacturing sector grew only modestly from 16.4 percent to 18.1 percent. Instead, the sector that registers the largest growth is "other services," which includes public services, teaching and research, restaurants and hotels, and other miscellaneous services. Table VII.2 disaggregates the manufacturing sector further and shows that while relatively low-skilled industries such as textiles and food products have grown, more skill-intensive industries such as "chemicals" and "fabricated metal products" have declined. There is little indication that more skilled industries expanded within manufacturing.

We decompose the change in the share of workers with post-secondary education into the two components according to the following formula:

$$
\Delta E_{j t}=\Sigma_{i} \lambda_{i j}\left(\Delta E_{i t}\right)+\Sigma_{i}\left(\Delta \lambda_{i j} E_{i}\right) .
$$


The term $\lambda_{i j}$ is the share of workers with post-secondary schooling in industry $i$ and $\Delta E_{i t}$ is employment growth of industry $i$. The first term corresponds to the "between" component and captures the extent to which growth in share of workers with postsecondary schooling was due to differential growth across industries. The second term reflects within-industry skill upgrading. This type of decomposition analysis is most commonly conducted using detailed industry-level data from the manufacturing sector (Berman, Bound, and Griliches (1994), Berman, Bound, and Machin(1998)). We use household survey data as does Autor, Katz, and Krueger (1998) and therefore our results are most comparable to their results for the U.S. economy. Using household survey data has its advantages and disadvantages. One clear advantage is that we can examine economy-wide changes in skill upgrading and examine manufacturing and nonmanufacturing sectors separately. Another advantage is that education is a cleaner measure of skill than the production worker and non-production worker distinction used in industry-level studies. The disadvantage is that household survey data lack fine industry classifications and would tend to misclassify between-industry movements as within-industry movements. We use 35 industry classifications, the finest that are available which can be matched consistently for the years 1989-2000. We focus on changes over 1989-1994, during which the skill premium rose rapidly, and over 19962000, during which the skill premium remained stable. ${ }^{7}$

The top panel of table VII.3 reports changes in employment shares (in efficiency units) while the bottom panel reports changes in wage bill shares. Table VII.3 shows that during the early period, 1989-1994, between- industry shifts accounted for roughly half

\footnotetext{
${ }^{7}$ In earlier versions we used 128 industry classifications which can be consistently matched from 19891998. We use the more aggregated industry categories in this version to include 2000 in the analysis.
} 
$(.154 / .301)$ of the rise in share of educated workers in terms of employment, and nearly one-third (.58/1.85) in terms of wage bill share. This is despite the fact that our industry measures most likely understate the role of between-industry shifts. In contrast to studies which focus on urban areas, our estimates of between-industry shifts are likely to be larger due to the inclusion of the agricultural sector. Table VII.1 documented the dramatic decline in agriculture which mostly employed low skilled labor.

During the latter period, 1996-2000, between-industry shifts actually favored lessskilled workers. Between-industry shifts predict a decline in the wage bill share of postsecondary workers of .36 percentage points per year during this period. One possibility is that product and factor price changes predicted by the Heckscher-Ohlin model have finally taken hold after a turbulent decade of tariff reductions and reforms. Another possibility, as suggested in Hanson (2003), is that tariff reductions related to NAFTA affected the more skill-intensive sectors. Whatever the cause, between-industry shifts account for none of the continued increase in skill demand in the later period.

Table VII.3 also provides a comparison of manufacturing and non-manufacturing sectors. While many of the detailed industry studies that attempt to disentangle the effects of trade and technology have been based on the manufacturing sector (Revenga (1997), Hanson and Harrison (1999) and Esquivel, Rodriguez-Lopez (2003)) the bottom panel of table VII.3 shows that skill demand increased even faster in the nonmanufacturing sector. The table points to the difficulty in empirically disentangling the effects of trade and technology. On the one hand, the rapid skill-upgrading in the nonmanufacturing sector suggests that industry studies which focus on manufacturing leave us with an incomplete picture of skill demand. On the other hand, the lack of fine 
industry classifications on household datasets, as well as the absence of data on capital and technology, makes it difficult to uncover the underlying factors behind withinindustry demand shifts documented here.

\section{Foreign Direct Investment and Outsourcing}

Another possible explanation for the increase in skill demand is the flow of foreign direct investment, and the movement of intermediate inputs across borders which is often labeled "outsourcing.” Feenstra and Hanson (1996) argue that the least skillintensive stage of production in the U.S. may be the most skill-intensive stage in Mexico. Therefore, when U.S. companies “outsource” the production of intermediate goods to Mexico, skill demand could increase in both countries. More generally, foreign direct investment may raise skill demand in Mexico because foreign companies bring more capital, which is complementary with skilled labor. The flow of foreign capital into Mexico did accelerate during the early 1990s when inequality rapidly increased (Edwards (1999)). While this coincident timing at the national level is suggestive, we lack crosscountry data to fully test the importance of foreign direct investment on wage inequality and skill premiums. Following the strategy used by Feenstra and Hanson (1997) we exploit cross-state variation in skill demand and employment in maquiladoras (offshore assembly plants). Figure VIII.1 shows the increase in maquiladora employment since the early 1980s. Figure VIII.2 shows that the region near the U.S. border dominates both the level and the increase in maquiladora employment. Table VIII.1 reports the wage bill share of workers with post-secondary schooling by region. The table shows that skill- 
upgrading was rapid in the border region between 1984 and 1989, consistent with Feenstra and Hanson (1997) which covers a similar time period. However, table VIII.1 also shows that skill upgrading in the border region was much slower than in other regions since 1989 when inequality rose sharply as documented in our data. In fact, since 1996 the wage bill share of post-secondary workers actually fell in the border region. Unlike the 1980s, we find that foreign direct investment in the form of outsourcing is an unlikely candidate explanation for the inequality increase in the 1990s. ${ }^{8}$

\section{Conclusion}

A number of papers have studied wage inequality in developing countries in the interest of testing the implications of trade models. Contrary to predictions, researchers have found that wage inequality increased in many developing countries with the opening of trade. In Mexico's case as well as many others that engage in trade liberalization, the opening to trade coincided with a whole-sale adoption of many other market-oriented policies such as privatization, domestic financial market reform, capital account liberalization, and tax reform. While trade flows based on comparative advantage and factor endowments may have compressed the wage structure, these effects were likely swamped by the disequalizing impact of market oriented reforms. Some of these reform effects appear to be short-lived, as suggested by Behrman, Birdsall, and Szekeley (2000). After a sharp increase in inequality during the first decade of reforms, 1984-1994, overall wage inequality fell and education premiums stabilized in Mexico. We find that the

\footnotetext{
${ }^{8}$ We also examined the 1980s and 1990 Mexican census data due to concerns that ENIGH may not be representative at the state and region level. We found qualitatively similar results which we do not report
} 
slowdown was due to a combination of factors. During 1994-1995, the Mexican economy underwent a serious macroeconomic crisis which more adversely impacted educated and skilled workers. The supply of post-secondary workers also rose, accounting for some of the slowdown in inequality growth. Finally, demand for skill slowed during the latter part of the 1990s. The slowdown in demand suggests that part of the initial impact of reforms have dissipated. On the other hand, the opening of the economy to trade, foreign capital, and global markets, appears to have unleashed forces which continue to increase the demand for skill.

We find that between-industry demand shifts actually reduced skill demand in the latter half of the 1990s. Despite this suggestion that trade flows finally had the equalizing impact predicted by Heckscher-Ohlin, within-industry demand shifts more than offset these effects and continued to favor educated workers. While consistent with skill biased technical change, our household data are not ideally suited for answering what precisely accounts for within-industry skill upgrading. We do find, however, that foreign direct investment in the form of outsourcing is unlikely to be the explanation. Our argument is based on comparisons across regions. While maquiladora employment increased the most along the U.S. border region, the increase in skill demand (proxied by wage bill shares of post-secondary worker) significantly lagged behind other regions.

here. These results are available from the authors upon request. 


\section{$\underline{\text { References }}$}

Attanasio, O., Goldberg P., and Nina Pavcnik (2003), "Trade Reforms and Wage Inequality in Colombia,” National Bureau of Economic Research Working Paper No. 9830.

Attanasio, O., and M. Szekely (2001), "Wage Shocks and Consumption Variability in Mexico During the 1990s.” Inter-American Development Bank Working Paper 451.

Autor, D., Katz, L. (1999), “Changes in the Wage Structure and Earnings Inequality,” Ashenfelter, Orley; Card,David, eds. Handbook of Labor Economics, Volume 3A New York: North-Holland.

Autor, D., Katz, L. (1999), "Changes in the Wage Structure and Earnings Inequality,” Ashenfelter, Orley; Card,David, eds. Handbook of Labor Economics, Volume 3A New York: North-Holland.

Autor, D., Katz, L., and A. Krueger (1998), “Computing Inequality: Have Computers Changed the Labor Market?” Quarterly Journal of Economics, 113:1169-1211.

Bartel,Ann P., and Frank Lichtenberg (1987), "The Comparative Advantage of Educated Workers in Implementing New Technology,” Review of Economics and Statistics, 69(1): 1-11.

Behrman, J., Birdsall, N., and M. Szekely (2000), "Economic Reform and Wage Differentials in Latin America,” Inter American Development Bank Working Paper No. 435.

Berman, E., Bound, J., and Z.Griliches (1994) "Changes in the Demand for Skilled Labor Within U.S. Manufacturing: Evidence from the Annual Survey of Manufacturers,” Quarterly Journal of Economics, 109: 367-398.

Berman,Eli; Bound,John, and Stephen Machin (1998), "Implications of Skill-Biased Technological Change: International Evidence,” Quarterly Journal of Economics, 113(4): 1245-79.

Berman, Eli, and Stephen Machin (2000), "Skill-Biased Technology Transfer: Evidence of Factor Biased Technological Change in Developing Countries,” Working paper, January 2000.

Borjas,G and Valery Ramey (1995), "Foreign Competition, Market Power, and Wage Inequality,” Quarterly Journal of Economics, 110(4): 1075-1110. 
Bound, J and Johnson, G (1992), "Changes in the Structure of Wages in the 1980s: An Evaluation of Alternative Explanations,” American Economic Review 82(3):37192.

Cragg, Michael and Mario Epelbaum (1996), "Why has Wage Dispersion Grown in Mexico? Is it the Incidence of Reforms or the Growing Demands for Skills?" Journal of Development Economics, 59: 99-116.

Edwards, Sebastian (1999), "Capital Flows to Latin America,” Martin Feldstein, ed., International Capital Flows, Chicago: University of Chicago Press.

Esquivel, Gerardo, and Jose Antonio Rodriguez-Lopez (2003), “Technology, Trade, and Wage Inequality in Mexico Before and After NAFTA,” Journal of Development Economics, 72: 543-565.

Feenstra, Robert, and Gordon Hanson (1997), "Foreign Direct Investment and Relative Wages: Evidence from Mexico's Maquiladoras,” Journal of International Economics, 42(3): 371-94.

Feliciano, Zadia (2001), "Workers and Trade Liberalization: The Impact of Trade Reforms in Mexico on Wages and Employment," Industrial and Labor Relations Review, 55(1):95-115.

Galor,Oded, and Daniel Tsiddon (1997), "Technological Progress, Mobility, and Economic Growth,” American Economic Review, 87(3): 363-82.

Hamnett, Brian R.(1999), A Concise History of Mexico, Cambridge Press.

Hanson, Gordon (2003), "What Has Happened to Wages in Mexico Since NAFTA?” National Bureau of Economic Research Working Paper No. 9563.

Hanson, Gordon, and Ann Harrison (1999), "Trade and Wage Inequality in Mexico," Industrial Labor Relations Review, 52(2): 271-288.

Juhn,C, Murphy,K, and B. Pierce (1993), "Wage Inequality and the Rise in Returns to Skill,” Journal of Political Economy 101(3): 410-42.

Katz, Lawrence, and Kevin M. Murphy (1992), “Changes in Relative Wages, 1963-1987: Supply and Demand Factors,” Quarterly Journal of Economics, 107(1): 35-78.

Krueger, Alan (1993), "How Computers Have Changed the Wage Structure: Evidence from Microdata, 1984-1989,” Quarterly Journal of Economics, 108(1): 33-60.

Leamer, Edward (1996), "In Search of Stolper-Samuelson Effects on U.S. Wages,” National Bureau of Economic Research Working Paper No. 5427. 
McKenzie, David (2001), “The Consumer Response to the Mexican Peso Crisis,”working paper, Stanford University.

Melendez, Jorge. (2001) “The Structure of Wages under Trade Liberalization: Mexico from 1984 to 1998,” Ph.D. Dissertation, University of Chicago.

Meza-Gonzalez, Liliana (1997), “The Mexican Wage Structure: 1988-1993,” Ph.D. Dissertation, University of Houston.

Morley,S, Machado, R, and S. Pettinato (1999) “Indexes of Structural Reform in Latin America,” Serie Reformas Económicas No. 12, ECLAC.

Murphy,K, and F. Welch (1992), “The Structure of Wages,” Quarterly Journal of Economics, 107(1): 285-326.

Nelson, R. and Edmund Phelps (1966), "Investment in Humans, Technological Diffusion, and Economic Growth,” American Economic Review Papers and Proceedings, 56: 69-75.

Pavcnik, Nina (2002), “What Explains Skill Upgrading in Less Developed Countries?” working paper, Dartmouth College.

Revenga, Ana L. (1997), “Employment and Wage Effects of Trade Liberalization: The Case of Mexican Manufacturing,” Journal of Labor Economics; 15(3): S20-43.

Robbins, Donald J. (1996), "HOS Hits Facts: Facts Win; Evidence on Trade and Wages in the Developing World,” Development Discussion Paper No. 557, H.I.I.D.

Robertson, Raymond (2001), “Relative Prices and Wage Inequality: Evidence from Mexico,” working paper, Macalester College.

Roett, Riordan(1998), Mexico's Private Sector : Recent History, Future Challenges Boulder : Lynne Rienner, 1998

Schultz, T. (1975), “The Value of the Ability to Deal with Disequilibria,” Journal of Economic Literature, 13(3):827-46.

Szekely, Miguel (1998), The Economics of Poverty, Inequality and Wealth Accumulation in Mexico. St Martin’s Press.

Welch, F. (1970), “Education in Production,” Journal of Political Economy; 78(1): 35-59.

Wood, Adrian (1994), North-South Trade, Employment, and Inequality.Oxford: Clarendon Press. 
Wood, Adrian (1997), "Openness and Wage Inequality in Developing Countries: The Latin American Challenge to East Asian Conventional Wisdom,” World Bank Economic Review, 11(1): 33-57. 


\section{Figure III.1}

\section{Real per capita GDP, Mexico}

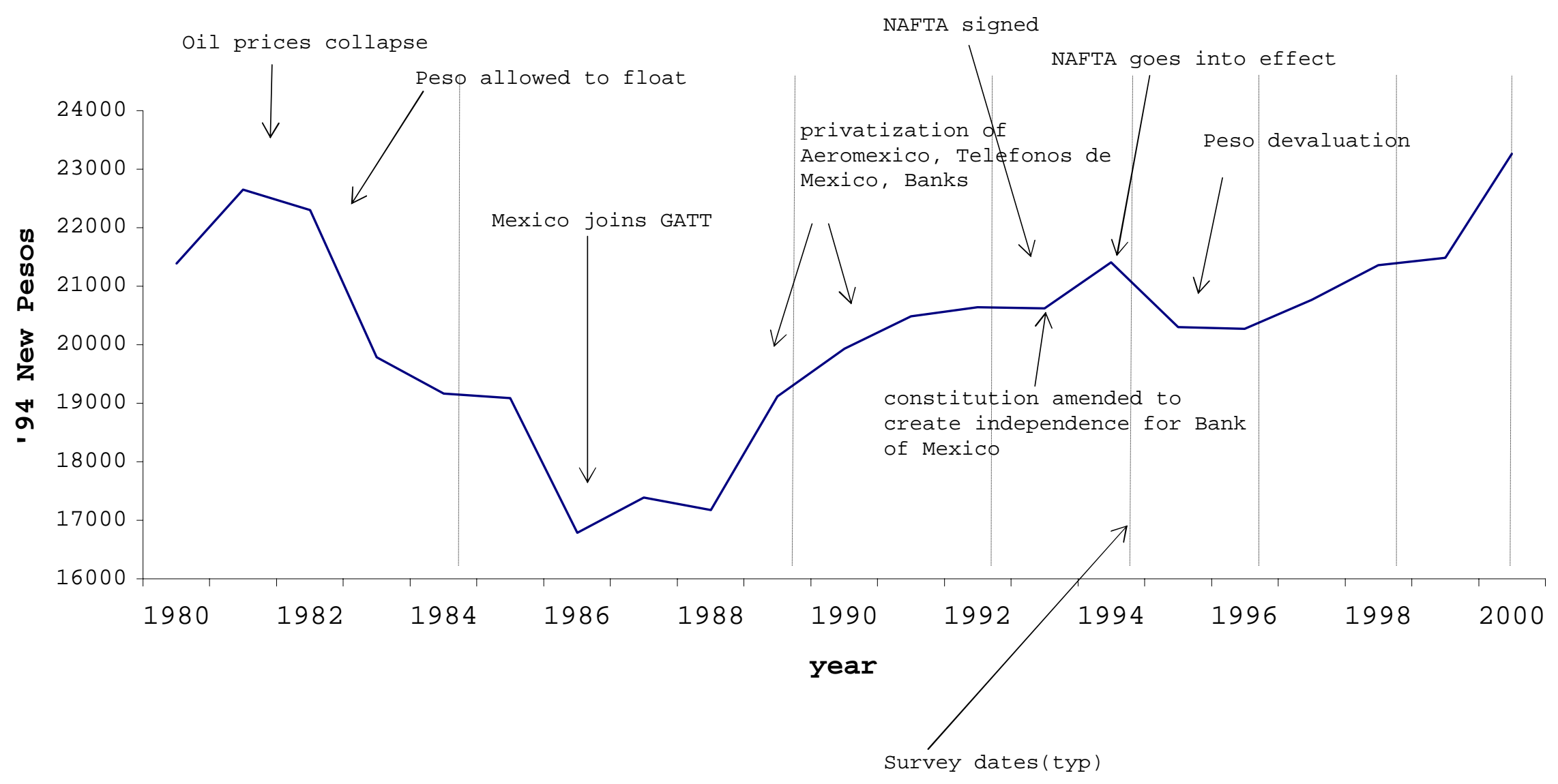




\section{Figure III.2}

Reform Index- Mexico: 1970-1995

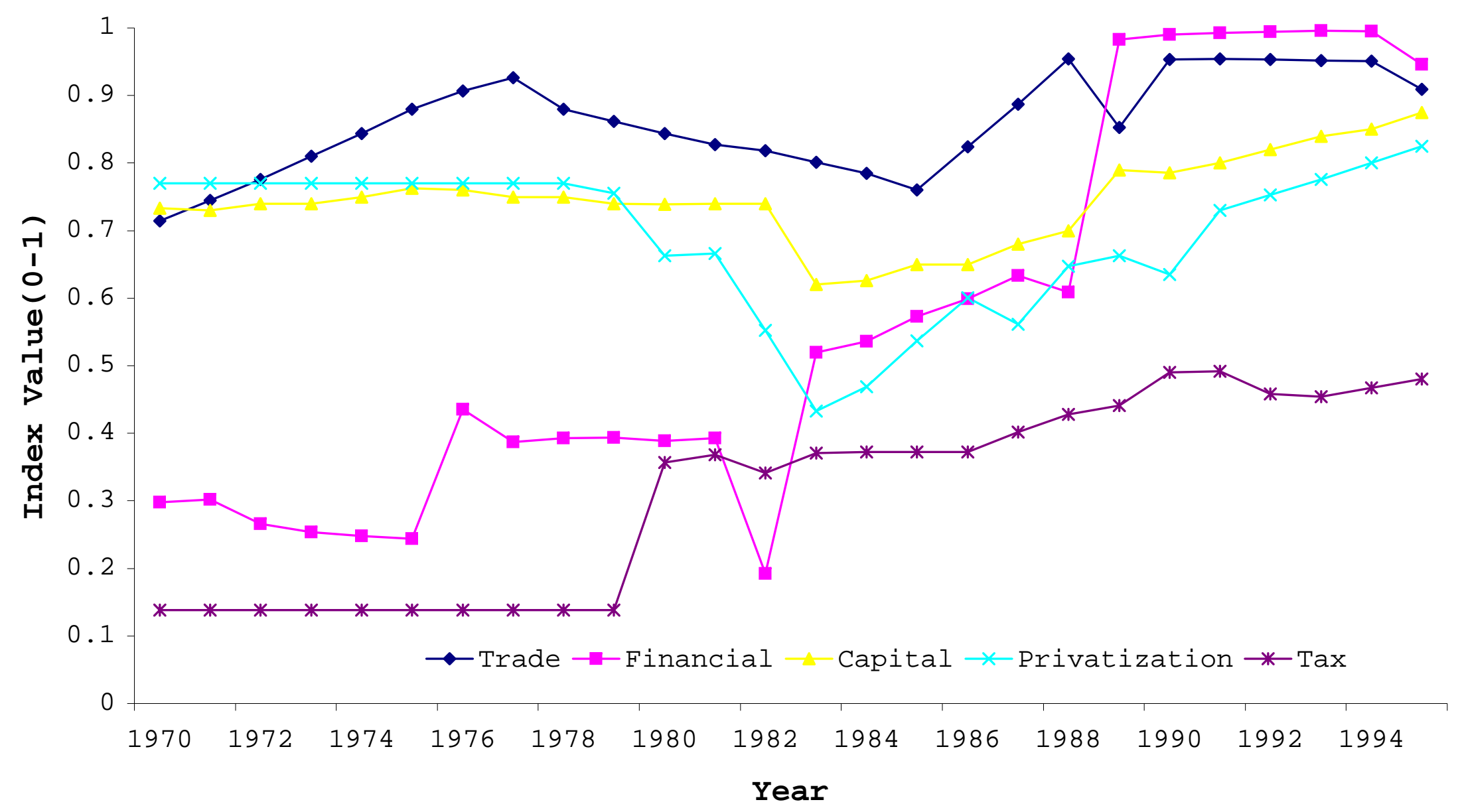

Indexes of Reform as compiled by Morley, Machado, and Pettinato(1999) 


\section{Table IV.1}

\section{Comparison of Mexican Household Datasets, selected years Urban Employment$$
\text { Survey ENIGH }
$$

individuals ages 16-65

Number of observations

$\%$ male

$\%$ fulltime

Educational Attainment

\section{None}

Primary

Secondary

High-School

Post High-School

\begin{tabular}{cc}
1992 & 1992 \\
\hline 420,548 & 27,772 \\
$52.7 \%$ & $48.2 \%$ \\
$49.5 \%$ & $49.2 \%$
\end{tabular}

$\begin{array}{rr}4.6 \% & 13.0 \% \\ 34.9 \% & 43.1 \% \\ 23.7 \% & 24.5 \% \\ 22.8 \% & 10.4 \% \\ 14.0 \% & 9.0 \%\end{array}$


Table V.1

Real Wage Changes, Mexico 1984-2000

\begin{tabular}{|c|c|c|c|c|c|c|}
\hline \multirow{2}{*}{$\begin{array}{c}\text { Men } \\
\text { quintile }\end{array}$} & \multicolumn{4}{|c|}{ change in average log hourly wage } & \multirow[b]{2}{*}{$\underline{1996-1998}$} & \multirow[b]{2}{*}{$1998-2000$} \\
\hline & $\underline{1984-1989}$ & $\underline{1989-1992}$ & $\underline{1992-1994}$ & $\underline{1994-1996}$ & & \\
\hline 1 & 0.09 & -0.04 & -0.06 & -0.35 & 0.09 & 0.19 \\
\hline 2 & -0.04 & -0.04 & -0.04 & -0.33 & 0.04 & 0.18 \\
\hline 3 & -0.03 & -0.06 & -0.02 & -0.34 & 0.06 & 0.17 \\
\hline 4 & 0.03 & -0.06 & 0.02 & -0.33 & 0.06 & 0.13 \\
\hline 5 & 0.09 & 0.04 & 0.15 & -0.43 & 0.06 & 0.15 \\
\hline
\end{tabular}

Women

$\begin{array}{lrrrrrr}1 & 0.14 & -0.15 & 0.06 & -0.39 & 0.02 & 0.21 \\ 2 & -0.11 & -0.07 & 0.02 & -0.37 & 0.04 & 0.18 \\ 3 & -0.13 & -0.04 & 0.04 & -0.37 & 0.03 & 0.18 \\ 4 & -0.07 & -0.01 & 0.10 & -0.41 & 0.09 & 0.14 \\ 5 & 0.05 & 0.07 & 0.20 & -0.43 & 0.08 & 0.08 \\ & & & & & & \\ & 0.01 & -0.04 & 0.03 & -0.36 & 0.06 & 0.16\end{array}$

Sample includes 15-64 year old male and female workers with no self-employment earnings. Wages are calculated as monthly earnings divided by (4.33 $x$ weekly hours). Earnings are deflated by national consumer price index (Bank of Mexico). 
Table V. 2

Inequality Measures, Log Hourly Wage

$\begin{array}{llllllll}\text { Men } & \underline{1984} & \underline{1989} & \underline{1992} & \underline{1994} & \underline{1996} & \underline{1998} & \underline{2000} \\ \text { std } & 0.77 & 0.78 & 0.81 & 0.88 & 0.85 & 0.84 & 0.83 \\ 90-10 & 1.86 & 1.82 & 1.86 & 2.16 & 2.06 & 2.05 & 2.00 \\ 90-50 & 0.90 & 1.02 & 1.05 & 1.29 & 1.17 & 1.20 & 1.14 \\ 50-10 & 0.95 & 0.80 & 0.81 & 0.87 & 0.89 & 0.85 & 0.87 \\ \text { Women } & & & & & & & \\ \text { std } & 0.75 & 0.72 & 0.79 & 0.84 & 0.83 & 0.85 & 0.80 \\ 90-10 & 1.83 & 1.73 & 1.99 & 2.12 & 2.05 & 2.05 & 1.92 \\ 90-50 & 0.77 & 0.92 & 1.05 & 1.22 & 1.14 & 1.17 & 1.08 \\ 50-10 & 1.06 & 0.82 & 0.94 & 0.90 & 0.91 & 0.88 & 0.84\end{array}$

Sample includes 15-64 year old male and female workers with no self-employment earnings. Wages are calculated as monthly earnings divided by (4.33 $x$ weekly hours). Earnings are deflated by national consumer price index (Bank of Mexico). 


\section{Figure V.1}

\section{Returns to Post-Secondary Education:1984-2000}

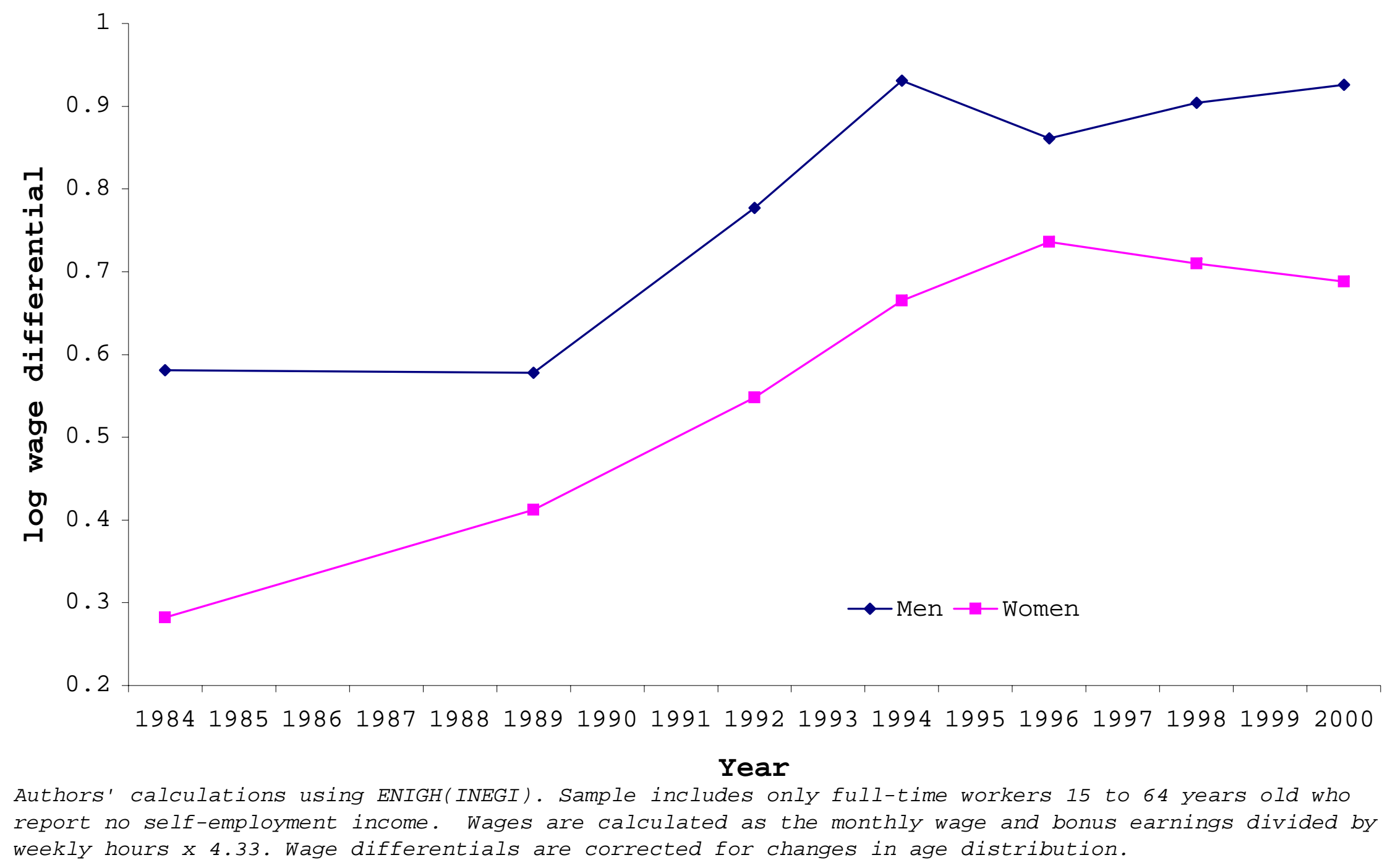




\section{Figure V.2}

\section{Returns to Secondary Education:1984-2000}

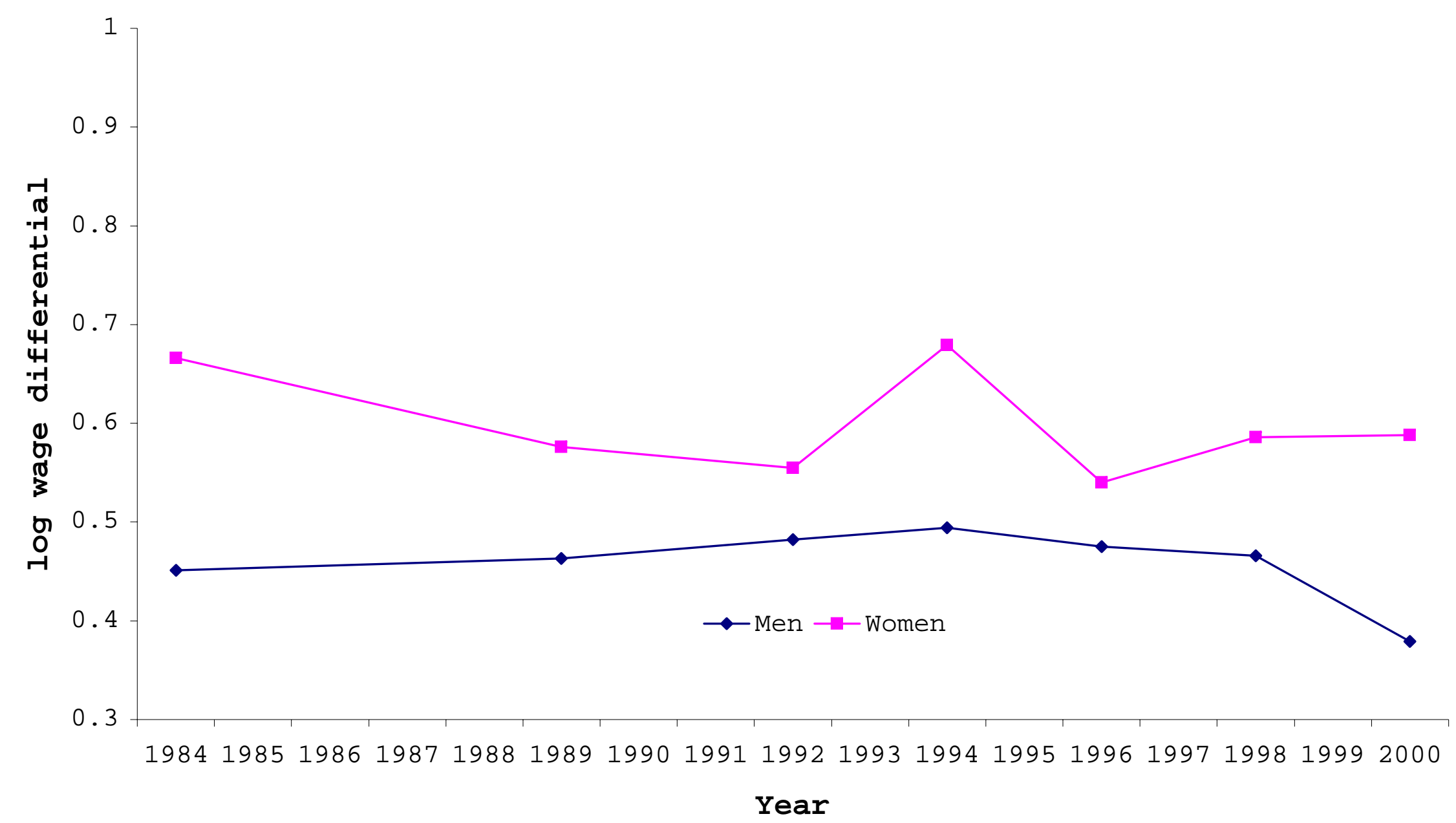

Authors' calculations using ENIGH(INEGI). See notes figure IV.3 wage differentials are corrected for changes in age distribution. 


\section{Figure V.3}

\section{Occupational Differentials:1984-2000 \\ High Skilled vs. Medium Skilled}

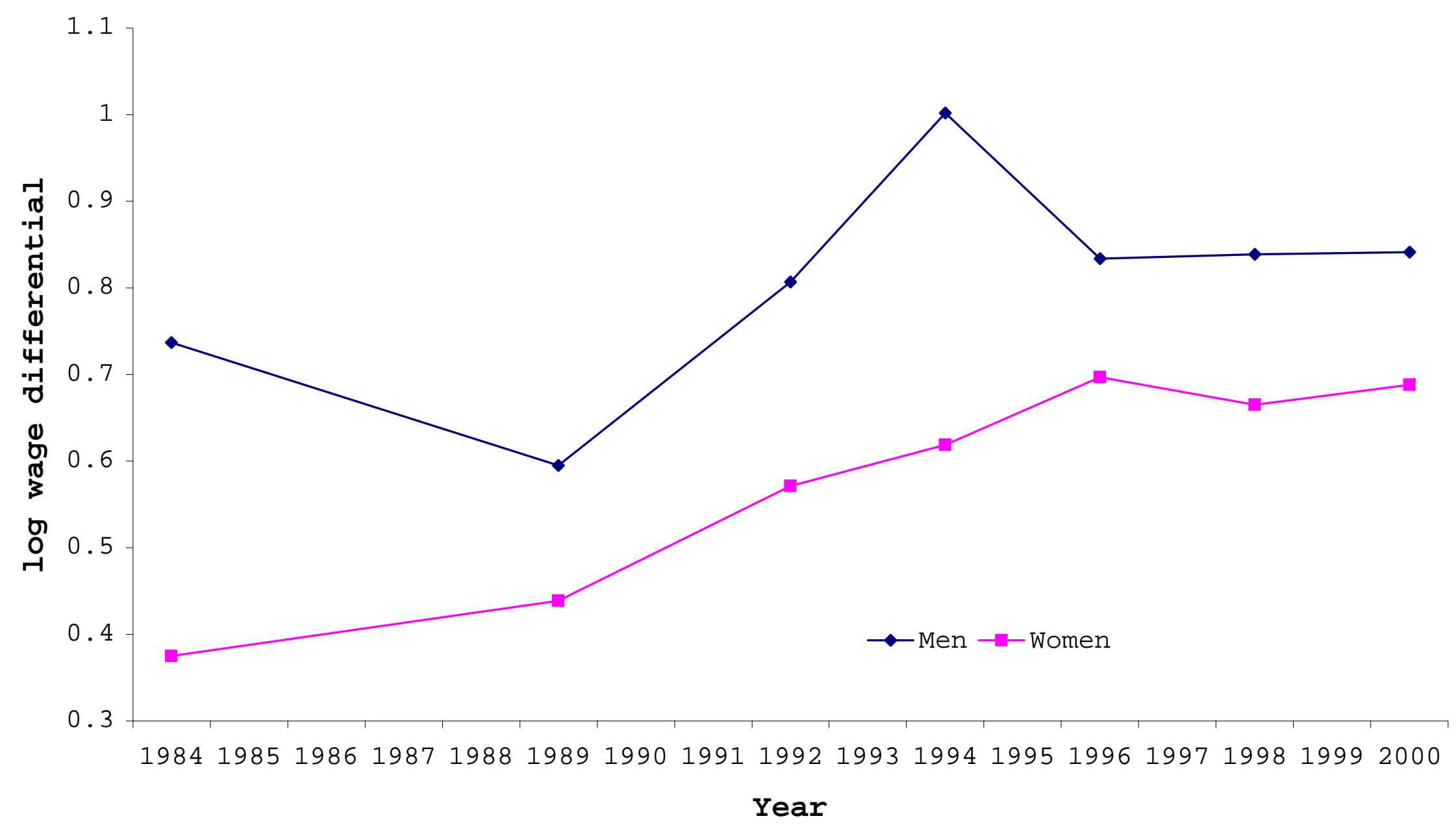

Authors' calculations using ENIGH(INEGI). Sample includes only full-time workers 15 to 64 years old who report no self-employment income. Wages are calculated as the monthly wage and bonus earnings divided by weekly hours $x$ 4.33. Wage differentials are corrected for changes in age distribution. 


\section{Figure V.4}

\section{Occupational Differentials:1984-2000 \\ Medium Skilled vs. Low Skilled}

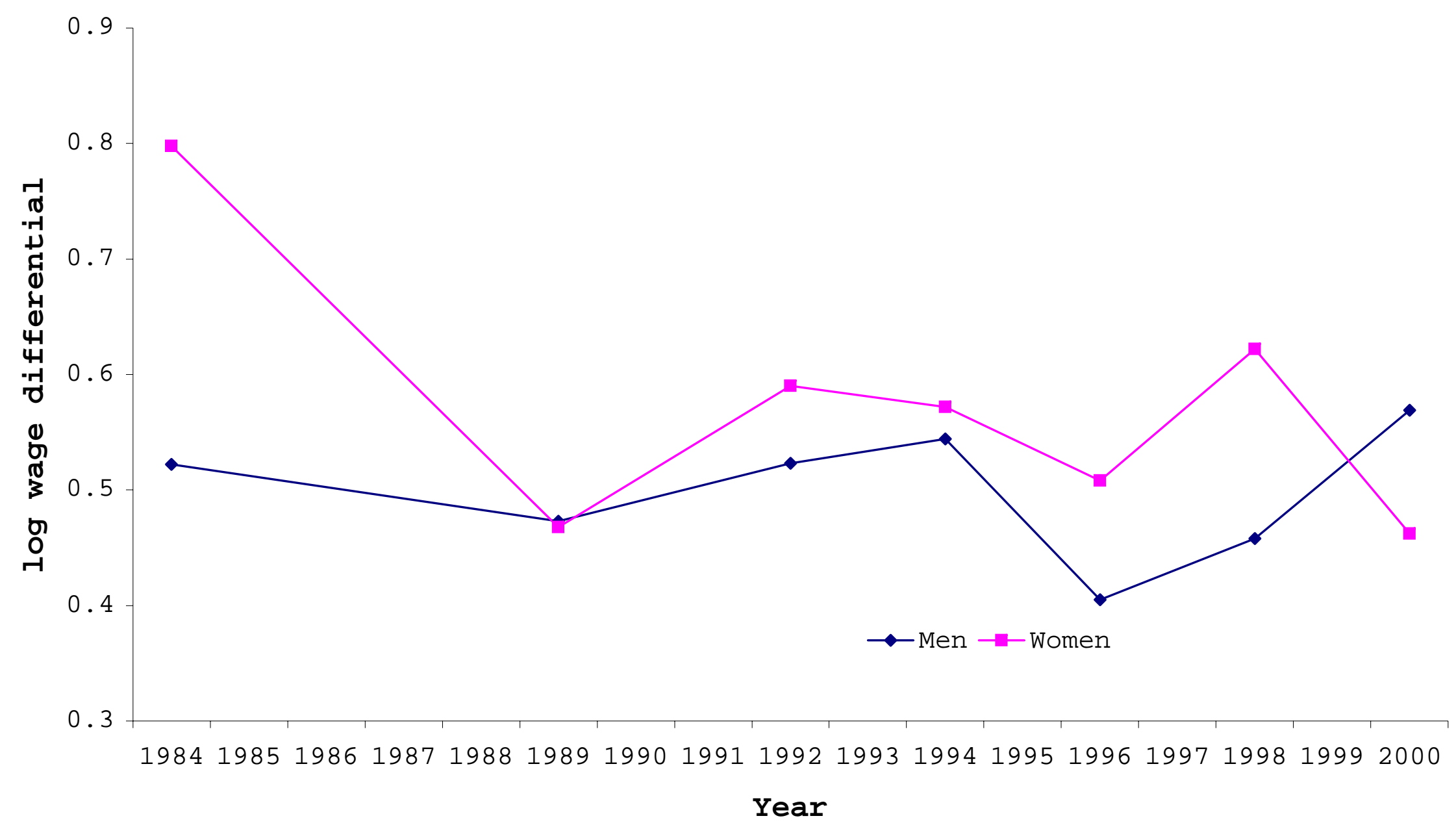

Authors' calculations using ENIGH(INEGI). Sample includes only full-time workers 15 to 64 years old who report no self-employment income. Wages are calculated as the monthly wage and bonus earnings divided by weekly hours $x$ 4.33. Wage differentials are corrected for changes in age distribution. 
Figure V.5
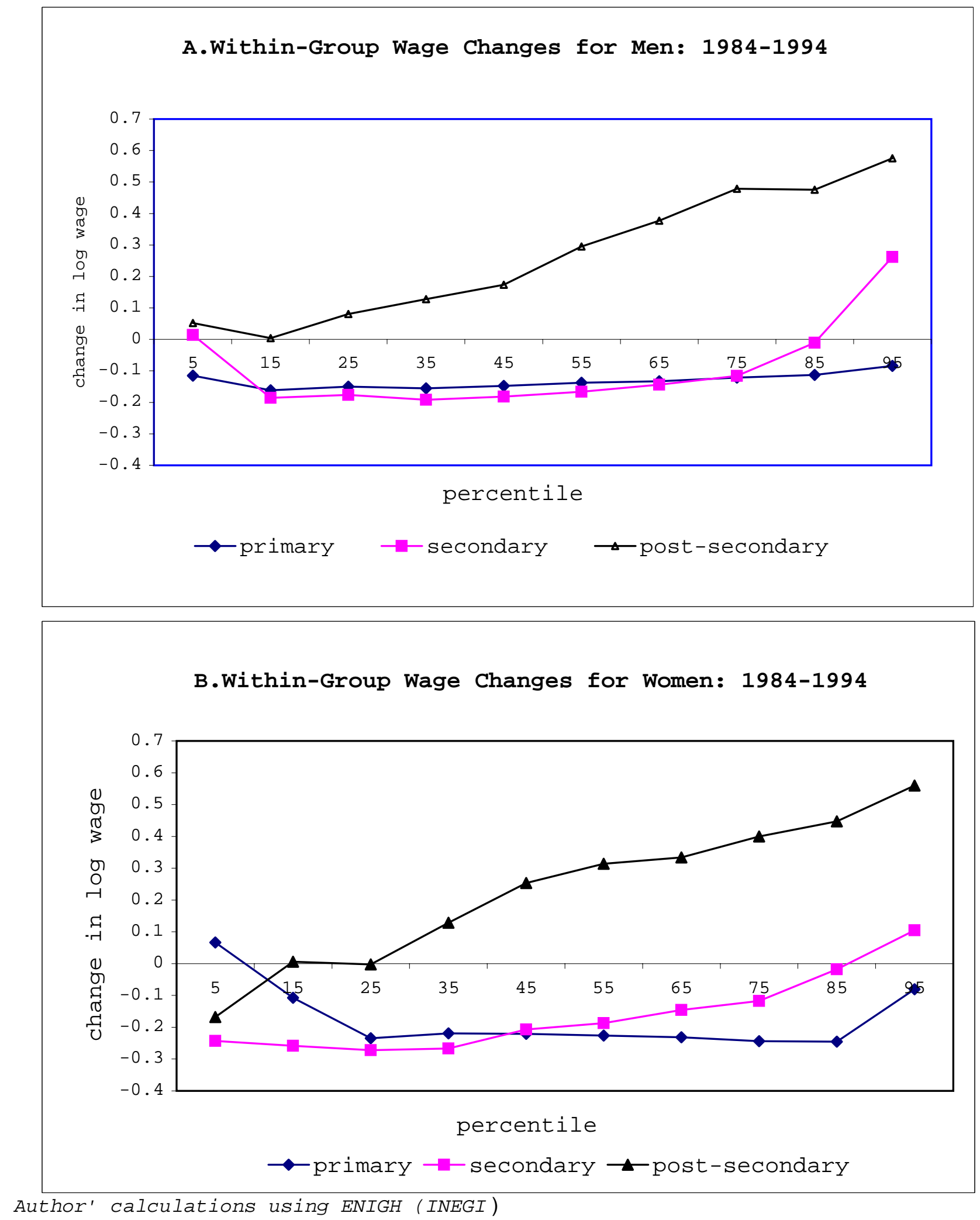
Figure V.6
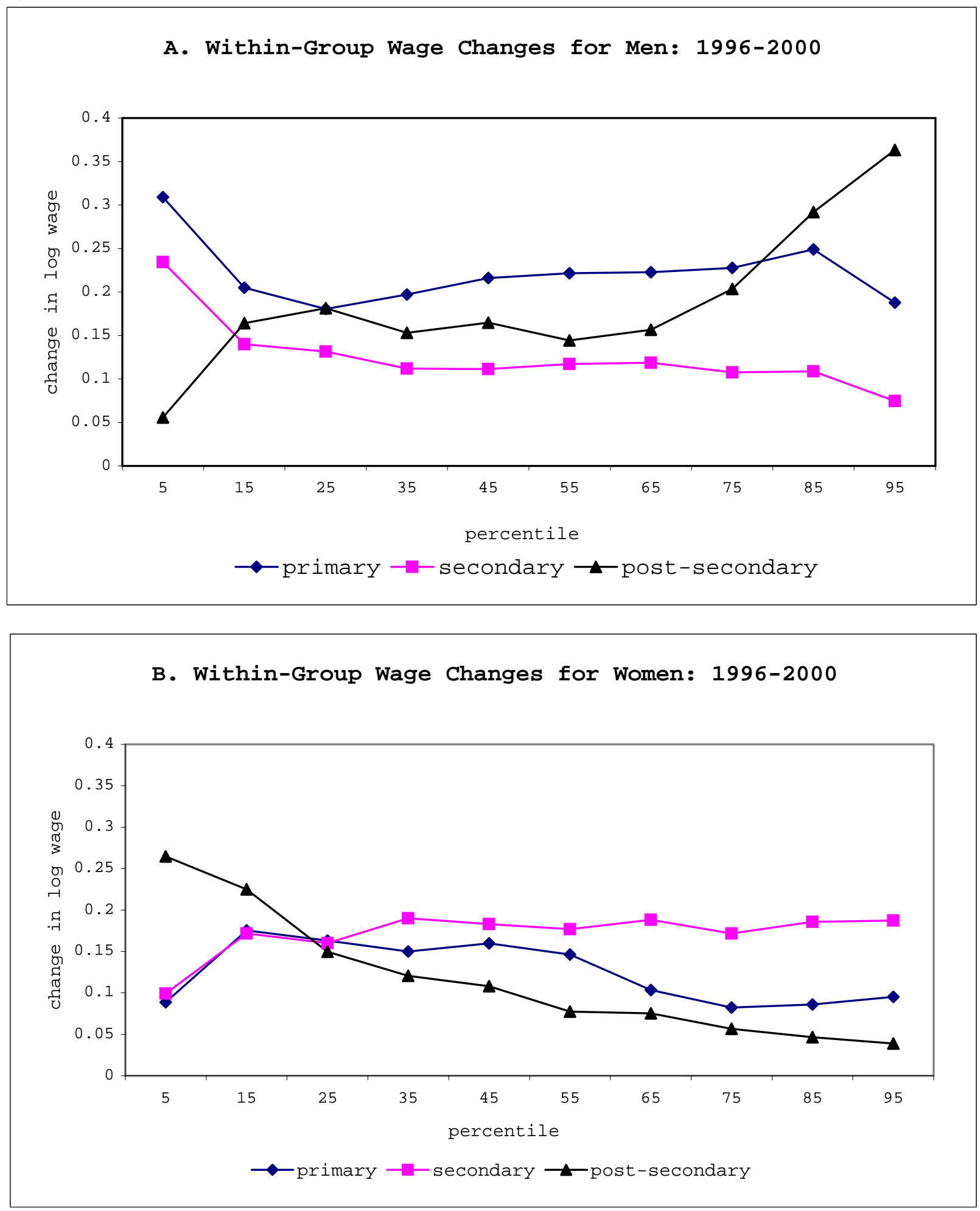

Author' calculations using ENIGH (INEGI) 
Table VI.1

Education Distribution: Men and Women 15-64

\begin{tabular}{|c|c|c|c|c|c|c|c|}
\hline A. Hours & $\underline{1984}$ & $\underline{1989}$ & $\underline{1992}$ & $\underline{1994}$ & $\underline{1996}$ & $\underline{1998}$ & $\underline{2000}$ \\
\hline Primary & 70.6 & 57.9 & 55.0 & 53.0 & 49.9 & 48.0 & 44.0 \\
\hline Secondary & 17.3 & 22.7 & 25.3 & 26.2 & 26.8 & 28.3 & 29.6 \\
\hline Post-Secondary & 6.8 & 10.3 & 10.2 & 11.0 & 11.6 & 11.6 & 13.8 \\
\hline B.Efficiency Units & $\underline{1984}$ & $\underline{1989}$ & $\underline{1992}$ & 1994 & 1996 & 1998 & $\underline{2000}$ \\
\hline Primary & 52.6 & 38.8 & 36.3 & 34.0 & 31.2 & 29.9 & 25.8 \\
\hline Secondary & 18.5 & 21.1 & 22.9 & 23.4 & 23.9 & 25.0 & 25.1 \\
\hline High School & 7.9 & 12.0 & 12.7 & 13.1 & 14.9 & 15.3 & 14.8 \\
\hline Post-Secondary & 21.0 & 28.0 & 28.2 & 29.6 & 30.0 & 29.8 & 34.3 \\
\hline C.Wage Bill & $\underline{1984}$ & $\underline{1989}$ & $\underline{1992}$ & 1994 & 1996 & $\underline{1998}$ & $\underline{2000}$ \\
\hline Primary & 55.3 & 41.5 & 36.1 & 30.5 & 30.5 & 28.6 & 25.4 \\
\hline High School & 7.4 & 12.6 & 13.1 & 13.7 & 14.8 & 15.2 & 13.9 \\
\hline Post-Secondary & 17.1 & 24.2 & 28.0 & 33.1 & 32.1 & 32.4 & 37.1 \\
\hline
\end{tabular}

Change in Share of Post-Secondary

(Annualized Log Change $\times 100$ )

1984-1994

2.1

1.5

2.9
1996-2000

1.9

1.5

1.6

Wage Bill

Sample includes 15-64 year old male and female workers with positive hours. The top panel reports hoursweighted shares. To calculate efficiency units and wage bills, we weight hours by group-specific average wages. For efficiency units, we fix the wage over years. For wage bills, we allow the averages to vary over time. See text for details. 


\section{Table VII. 1}

Industrial Distribution year

Industry

Agriculture

Mining and Mineral Extraction

Manufacturing

Electricity and water

Construction

Wholesale / Retail

Transportation and Communication

Financial Services

other Services $\begin{array}{lllllll}1984 & 1989 & 1992 & 1994 & 1996 & 1998 & 2000\end{array}$

$\begin{array}{rrrrrrr}23.2 & 17.2 & 13.6 & 13.8 & 11.8 & 11.5 & 9.6 \\ 1.0 & 1.7 & 1.1 & 0.8 & 0.8 & 0.7 & 0.5 \\ 16.4 & 16.7 & 18.4 & 17.1 & 17.6 & 17.2 & 18.1 \\ 2.0 & 0.7 & 0.7 & 0.7 & 0.8 & 1.0 & 0.8 \\ 5.7 & 6.8 & 7.9 & 7.2 & 5.9 & 5.2 & 5.1 \\ 15.5 & 16.5 & 17.7 & 17.5 & 17.1 & 19.3 & 18.0 \\ 5.5 & 4.5 & 4.3 & 5.4 & 5.6 & 5.2 & 5.8 \\ 4.4 & 2.8 & 2.5 & 2.6 & 2.0 & 1.9 & 2.7 \\ 26.3 & 33.2 & 34.1 & 35.1 & 38.5 & 38.1 & 39.3 \\ & & & & & & \\ 100 & 100 & 100 & 100 & 100 & 100 & 100\end{array}$

Source: Enigh(INEGI). The table reports shares of labor in efficiency units.

See text for details. 


\section{Table VII. 2}

Industrial Distribution: Manufacturing

\section{Industry}

Food products, drinks and tobacco

Textiles

Wood products

Paper products

chemicals

Petroleum and coal Products

Primary metal industries

Fabricated metal products

other manufacturing

Total

$$
\text { year }
$$

$\begin{array}{lllllll}1984 & 1989 & 1992 & 1994 & 1996 & 1998 & 2000\end{array}$

\begin{tabular}{rrrrrrr}
16.8 & 16.9 & 20.8 & 25.3 & 23.3 & 19.7 & 20.3 \\
\hline 16.2 & 20.3 & 17.5 & 17.3 & 19.1 & 20.3 & 23.21 \\
\hline 9.3 & 6.2 & 6.2 & 7.6 & 7.3 & 7.4 & 7.9 \\
\hline 5.3 & 8.0 & 5.1 & 5.7 & 6.2 & 6.2 & 1.7 \\
\hline 14.0 & 14.3 & 14.1 & 9.5 & 9.9 & 12.9 & 13.7 \\
\hline 7.2 & 5.4 & 9.7 & 7.0 & 5.5 & 5.1 & 0.8 \\
\hline 4.5 & 3.3 & 1.8 & 1.8 & 1.4 & 2.2 & 3.7 \\
\hline 24.1 & 23.9 & 23.6 & 24.3 & 25.5 & 24.9 & 26.5 \\
\hline 2.7 & 1.8 & 1.3 & 1.7 & 1.8 & 1.4 & 2.4 \\
\hline
\end{tabular}

10

$\begin{array}{lllllll}100 & 100 & 100 & 100 & 100 & 100 & 100\end{array}$

Source: Enigh(INEGI). The table reports shares of labor in efficiency units. 


\section{Table VII. 3}

Change in Share of Workers with Post-Secondary Education (100 x Annualized Change in Employment and Wage Bill Share)

A. Employment Share in Efficiency Units

\begin{tabular}{|c|c|c|c|c|c|c|c|c|c|}
\hline \multirow[b]{2}{*}{ Year } & \multicolumn{2}{|c|}{ All Industries } & \multicolumn{4}{|c|}{ Manufacturing } & \multicolumn{3}{|c|}{ Non-Manufacturing } \\
\hline & Between & Within & Total & Between & Within & Total & Between & Within & Total \\
\hline $1989-1994$ & 0.154 & 0.147 & 0.301 & -0.306 & -0.799 & -1.105 & 0.250 & 0.335 & 0.585 \\
\hline $1996-2000$ & -0.409 & 1.508 & 1.099 & -0.275 & 0.817 & 0.542 & -0.424 & 1.659 & 1.235 \\
\hline
\end{tabular}

B. Wage Bill Share

\section{All Industries \\ Manufacturing \\ Non-Manufacturing}

Year

$1989-1994$

$1996-2000$

Between Within Total

$\begin{array}{rrr}0.580 & 1.272 & 1.852 \\ -0.357 & 1.298 & 0.941\end{array}$

Between Within Total

$-0.377$

$-0.381$

0.414

0.037

0.813

0.432
Between Within Total

$0.792 \quad 1.464 \quad 2.256$

$-0.286 \quad 1.380 \quad 1.094$

Decompositions are based on 35 2-digit industry categories. workers are imputed using wages of wage and salary workers. reported in efficiency units. See Table VI.1 for details. 


\section{Figure VIII.1 Maquiladora Employment, Mexico}

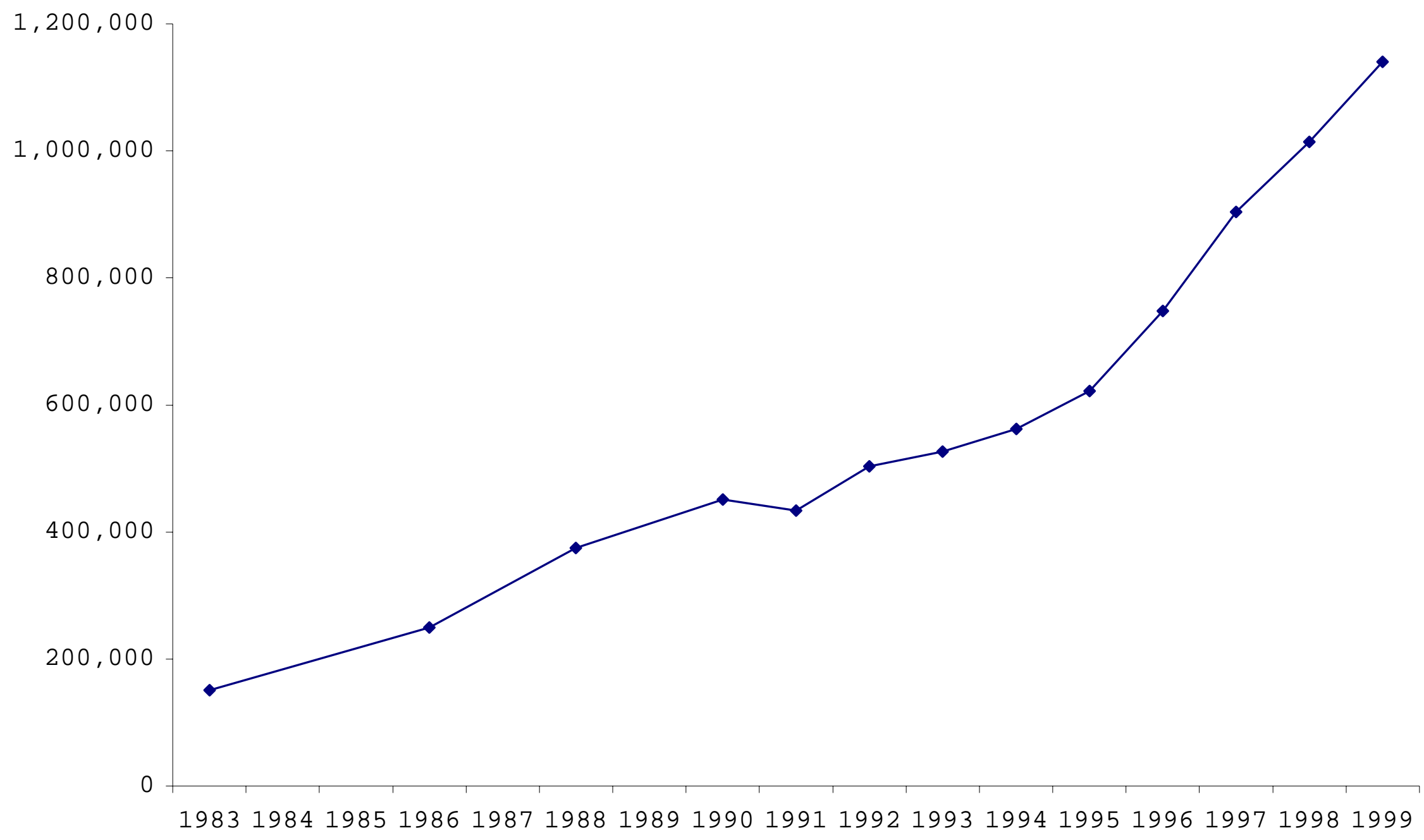




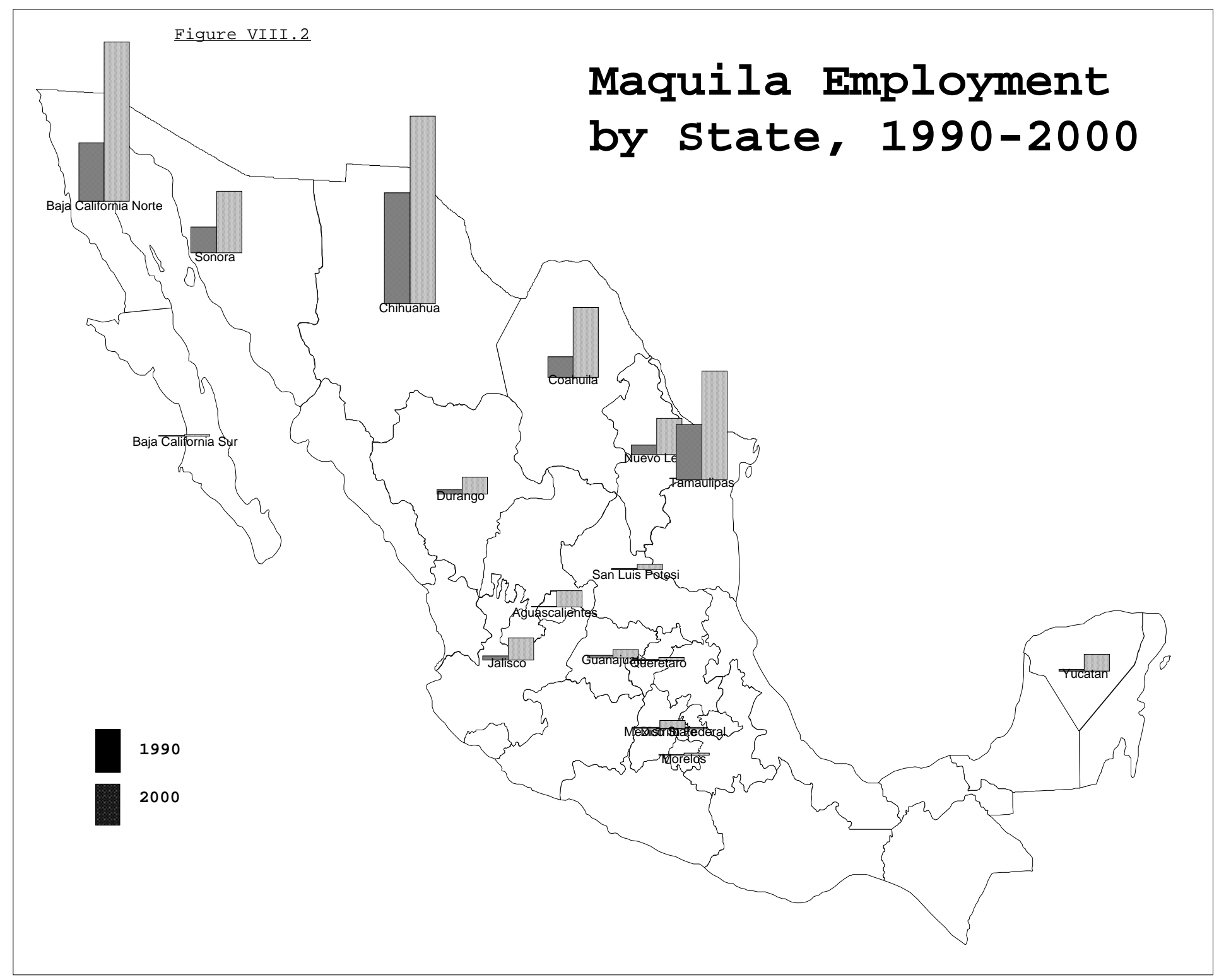




\section{Table VIII.1}

Wage Bill Share of Workers With Post-Secondary Education, by Region

Region

Border

North

Mexico City and Federal District

Central

South year

$\begin{array}{lllllll}1984 & 1989 & 1992 & 1994 & 1996 & 1998 & 2000\end{array}$

$0.162 \quad 0.307$

$0.119 \quad 0.177$

$0.275 \quad 0.289$

$0.108 \quad 0.172$

0.054

0.204

0.307

0.275

0.315

0.381

0.346

0.348

0.353

0.261

0.316

0.311

0.252

0.194

0.426

0.359

0.409

0.457

$\begin{array}{lllll}0.257 & 0.254 & 0.272 & 0.313\end{array}$

$\begin{array}{lllll}0.176 & 0.214 & 0.214 & 0.250 & 0.273\end{array}$

Source: Enigh(INEGI). 


\section{Appendix Table 1}

\section{Summary Statistics}

individuals ages 15 and over

Number of Observations

$\%$ male

$\%$ employed

$\%$ fulltime

Mean years of education(men)

Mean years of education(women)

\% Union

Average weekly hours

Average hourly wage(current pesos)

\begin{tabular}{rr|r|r|r|r|r}
\multicolumn{1}{c}{1984} & 1989 & 1992 & 1994 & 1996 & 1998 & 2000 \\
\hline 14,015 & 35,507 & 31,090 & 37,818 & 41,135 & 30,938 & 28,096 \\
$48.7 \%$ & $48.1 \%$ & $48.2 \%$ & $47.9 \%$ & $47.7 \%$ & $48.0 \%$ & $47.3 \%$ \\
$49.2 \%$ & $50.7 \%$ & $59.5 \%$ & $56.4 \%$ & $58.1 \%$ & $60.2 \%$ & $58.6 \%$ \\
$42.8 \%$ & $44.4 \%$ & $53.9 \%$ & $47.9 \%$ & $49.0 \%$ & $50.8 \%$ & $50.0 \%$ \\
5.39 & 6.05 & 6.12 & 6.21 & 6.63 & 6.65 & 7.08 \\
4.49 & 5.20 & 5.44 & 5.62 & 5.90 & 6.01 & 6.41 \\
$17.9 \%$ & $18.9 \%$ & $14.8 \%$ & $11.7 \%$ & $11.1 \%$ & $10.6 \%$ & $10.9 \%$ \\
47.1 & 47.1 & 47.1 & 46.5 & 46.5 & 46.1 & 45.9 \\
164.8 & 2695.7 & 5141.6 & 6.72 & 8.32 & 12.18 & 18.14
\end{tabular}




\section{Appendix Table 2}

Inequality Measures Including Self-employed Workers, Log Hourly Wage

$\begin{array}{llllllll}\text { Men } & \underline{1984} & \underline{1989} & \underline{1992} & \underline{1994} & \underline{1996} & \underline{1998} & \underline{2000} \\ \text { std } & 0.89 & 0.92 & 0.95 & 0.99 & 0.95 & 0.95 & 0.95 \\ 90-10 & 2.19 & 2.22 & 2.27 & 2.41 & 2.32 & 2.35 & 2.25 \\ 90-50 & 0.99 & 1.13 & 1.20 & 1.32 & 1.24 & 1.27 & 1.20 \\ 50-10 & 1.20 & 1.08 & 1.07 & 1.08 & 1.08 & 1.07 & 1.05 \\ \text { Women } & & & & & & & \\ \text { std } & 0.88 & 0.84 & 0.93 & 0.96 & 0.94 & 0.97 & 0.93 \\ 90-10 & 2.16 & 2.05 & 2.32 & 2.39 & 2.32 & 2.37 & 2.26 \\ 90-50 & 0.83 & 0.99 & 1.11 & 1.24 & 1.16 & 1.23 & 1.13 \\ 50-10 & 1.32 & 1.06 & 1.20 & 1.15 & 1.16 & 1.14 & 1.13\end{array}$

Sample includes 15-64 year old male and female workers with no self-employment earnings. Wages are calculated as monthly earnings divided by (4.33 $x$ weekly hours). Earnings are deflated by national consumer price index (Bank of Mexico). 